\title{
Spatio-temporal change in forest cover and carbon storage considering actual and potential forest cover in South Korea
}

\author{
NAM Kijun ${ }^{1}$, LEE Woo-Kyun ${ }^{1 *}$, KIM Moonil $^{1}$, KWAK Doo-Ahn ${ }^{2}$, BYUN Woo-Hyuk $^{1}$, \\ YU Hangnan ${ }^{1}$, KWAK Hanbin ${ }^{2}$, KWON Taesung ${ }^{3}$, SUNG Joohan ${ }^{3}$, CHUNG Dong-Jun ${ }^{4}$ \\ \& LEE Seung-Ho ${ }^{5}$ \\ ${ }^{1}$ Division of Environmental Science and Ecological Engineering, Korea University, Seoul 136-713, Republic of Korea; \\ ${ }^{2}$ GIS/RS Center for Environmental Resources, Korea University, Seoul 136-173, Republic of Korea; \\ ${ }^{3}$ Division of Forest Ecology, Korea Forest Research Institute, Seoul 130-712, Republic of Korea; \\ ${ }^{4}$ National Forestry Cooperative Federation, Daejeon 306-808, Republic of Korea; \\ ${ }^{5}$ Division of Forest Economics \& Management, Korea Forest Research Institute, Seoul 130-712, Republic of Korea
}

Received August 28, 2014; accepted September 18, 2014; published online February 6, 2015

\begin{abstract}
This study analyzes change in carbon storage by applying forest growth models and final cutting age to actual and potential forest cover for six major tree species in South Korea. Using National Forest Inventory data, the growth models were developed to estimate mean diameter at breast height, tree height, and number of trees for Pinus densiflora, Pinus koraiensis, Pinus rigida, Larix kaempferi, Castanea crenata and Quercus spp. stands. We assumed that actual forest cover in a forest type map will change into potential forest covers according to the Hydrological and Thermal Analogy Groups model. When actual forest cover reaches the final cutting age, forest volume and carbon storage are estimated by changed forest cover and its growth model. Forest volume between 2010 and 2110 would increase from 126.73 to $157.33 \mathrm{~m}^{3} \mathrm{hm}^{-2}$. Our results also show that forest cover, volume, and carbon storage could abruptly change by 2060. This is attributed to the fact that most forests are presumed to reach final cutting age. To avoid such dramatic change, a regeneration and yield control scheme should be prepared and implemented in a way that ensures balance in forest practice and yield.
\end{abstract}

climate change, final cutting age, carbon storage, national forestry inventory, forest growth model

Citation: $\quad$ Nam K, Lee WK, Kim M, Kwak DA, Byun WH, Yu H, Kwak H, Kwon T, Sung J, Chung DJ, Lee SH. Spatio-temporal change in forest cover and carbon storage considering actual and potential forest cover in South Korea. Sci China Life Sci, 2015, 58: 713-723, doi: 10.1007/s11427-014-4773-4

Climate change is a critical environmental issue. According to the Intergovernmental Panel on Climate Change (IPCC), there was an increase in global temperature of $0.74^{\circ} \mathrm{C}$ from 1906 to 2005, and temperature may increase an additional $1.1-6.4^{\circ} \mathrm{C}$ by the 2090s [1]. Climate change is expressed by a variety of phenomena including biological, chemical, and physical effects, even though the impacts of such changes appear slowly [2,3].

The forest ecosystem that is important in the global car-

*Corresponding author (email: leewk@korea.ac.kr) bon sink and cycle stores a large amount of total terrestrial organic carbon through the exchange of $\mathrm{CO}_{2}$ with the atmosphere [4]. Climatic change could result in the alteration of the distribution and function of the forest ecosystem [5-7]. Coniferous trees are more sensitive to climate change and so are likely to be replaced by deciduous trees in South Korea [8,9]. Moreover, the Korea Forest Service [10], announced that coniferous forest coverage gradually decreased, whereas deciduous and mixed forest areas increased. Therefore, it is important to understand which forest ecosystem processes induce such changes and how the system 
responds to climate change in terms of ecological and biogeographical studies [11-15].

Forest cover can change by natural or artificial regeneration, so the change modifies forest volume and carbon storage. Evaluation and monitoring of carbon storage and sequestration in South Korea is done by estimation of forest volume [16]. This volume can be converted to carbon storage using carbon emission factors proposed by the Korea Forest Research Institute [17].

There have been many studies with Dynamic Global Vegetation Models (DGVMs) to understand how climate change affects the ecosystem [18-24]. Several researchers have tried to apply DGVMs, such as the Holdridge [25], Carbon Exchange between Vegetation, Soil, and Atmosphere (CEVSA) model [8], and MAPSS-CENTURY (MC1) [26], models to predict the potential vegetation distribution in South Korea using past and future climatic data. However, such models reflecting potential forest cover distribution did not consider actual cover [27].

To overcome such limitations, we estimated future forest cover change considering both potential forest cover predicted by the Hydrological and Thermal Analogy Groups (HyTAGs) model [28] and actual forest covers in the 4th Forest Cover Map [29]. Previous studies of forest cover distribution in South Korea using MC1 and CEVSA showed that most current tree species would be replaced by Quercus spp. This is because the country is regarded as a single climatic zone towing to coarse resolution $[8,26]$, but there are in fact various climate and geographic conditions. What is important in this study is not the fact that all species are replaced by Quercus spp. but that HyTAG [28] showed reliable performance and results and implied the distributional probability of various tree species in future when compared with MC1 and CEVSA. Therefore, we employed the HyTAG to predict future forest cover various from climate change. Specifically, once a certain forest type reaches final cutting age, there would be artificial regeneration with the tree species predicted by HyTAG at that time. Therefore, we analyzed change in forest cover, forest volume and carbon storage over the next 100 years with a 10-year interval.

Lee et al. [30] proposed four prediction scenarios of future forest volume and carbon storage, considering both potential and actual forest covers: (i) Tree species unchanged; assuming current tree species are maintained, even under climate change; (ii) Natural regeneration; applies lag time (mortality delay) over which forest cover would naturally change; (iii) Artificial regeneration at final cutting age, i.e., forest cover reaching final cutting age should be regenerated to the potential forest cover. (iv) Immediate regeneration; actual forest cover, which is different from potential forest cover, should be immediately replaced by the latter. Of these four, we analyzed change in forest cover, forest volume, and carbon storage assuming scenario iii, which reflects forest management planning.

\section{Materials and methods}

\subsection{Study area}

The study area included all of South Korea, $33^{\circ} 09^{\prime}$ to $38^{\circ} 45^{\prime} \mathrm{N}$ and $124^{\circ} 54^{\prime}$ to $131^{\circ} 06^{\prime} \mathrm{E}$ (Figure 1). Currently, forests occupy $\sim 64 \%\left(6450438 \mathrm{hm}^{2}\right)$ of total land area in the country. As shown in Figure 1, evergreen needleleaf (mainly Pinus densiflora), deciduous broadleaf (mainly Quercus spp.), and mixed forests took up approximately $40.5 \%, 27 \%$, and $29.3 \%$ of total forest area in 2010, respectively [31]. These are the major tree species in the country and are important for their ecological, economical, and socio-cultural value [32].

\subsection{Korean National Forest Inventory (NFI) data}

NFI data were used to develop the forest growth models. The 5th NFI was conducted annually in all forest areas from 2006 to 2010. The NFI applied systematic cluster sampling on a $4 \mathrm{~km} \times 4 \mathrm{~km}$ grid. About 6200 plots were created for the

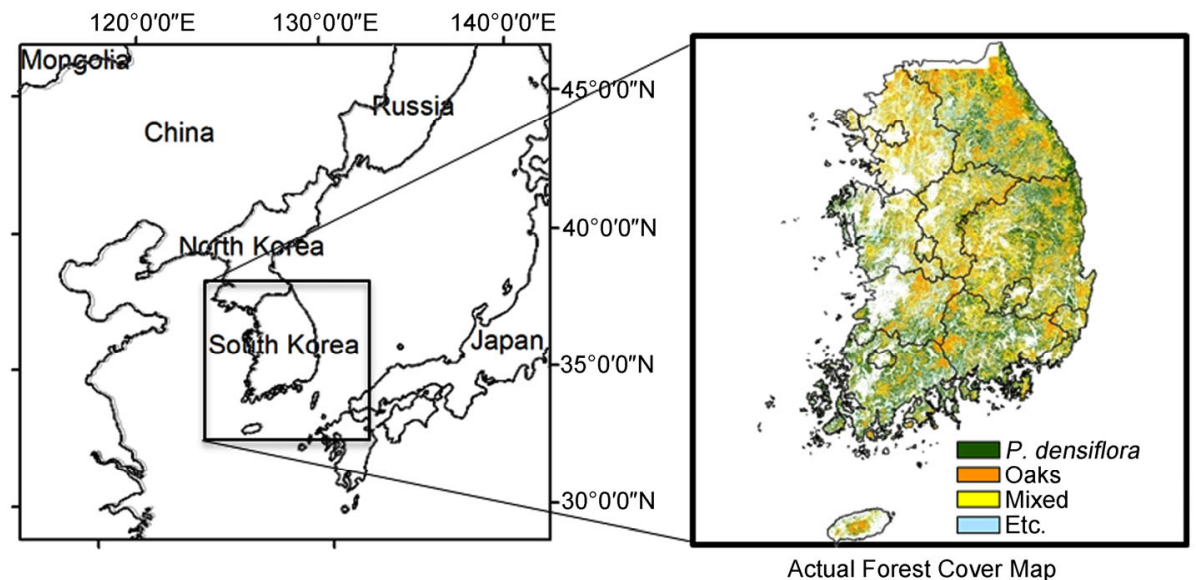

Figure 1 Geographic location and forest cover of the study area. 
entire Korean terrestrial area, of which $\sim 4000$ were in forest area. We used 4000 plots of NFI data that were surveyed during five years, beginning in 2006. Subplot 1 was the center plot and subplots 2,3 , and 4 were located $50 \mathrm{~m}$ away at azimuths $0^{\circ}, 120^{\circ}$, and $240^{\circ}$ from subplot 1 . Each subplot consisted of three different plots, a $0.08-\mathrm{hm}^{2}$ large tree plot of $16-\mathrm{m}$ radius, $0.04-\mathrm{hm}^{2}$ standard tree plot of $11.3-\mathrm{m}$ radius, and $0.003-\mathrm{hm}^{2}$ sapling plot of 3.1-m radius [31] (Figure $2)$. The NFI data were used to predict diameter at breast height $(D B H)$, tree height $(h)$, number of trees per $\mathrm{hm}^{2}$ (Nha), and stand volume.

\subsection{South Korean forest cover map}

The forest cover map (1:25,000 scale) was used to identify current forest cover and volume. The map was prepared by interpreting aerial photographs of South Korea [33]. We used the 4th forest cover map, produced between 1996 and 2005 , to estimate forest volume using the forest growth model developed with NFI data. The forest cover map contains information on tree species, $D B H$ class, age class, and canopy closure class. There were 18 categories of tree species. The $D B H$ class was grouped at $10-\mathrm{cm}$ intervals, and age class at 10-year intervals. Canopy closure was classified as coarse, medium and dense, according to crown projection area.

\subsection{Climate data}

The Korea Meteorological Administration (KMA) provides climatic data such as temperature, precipitation, wind, humidity and sunshine hours which were obtained from 75 meteorological stations over all South Korea. We used data (monthly mean temperature, mean daily minimum temperature, and accumulated precipitation) from 1971 through 2000. The data were interpolated to a $1-\mathrm{km}$ grid using a kriging algorithm and inverse distance squared weighting (IDW), considering absolute temperature and precipitation lapse rates with elevation [8,34-37]. Future climatic data were predicted under A1B scenarios focused on a balance of all energy sources from the Special Report on Emission Scenarios [38]. Datasets were resampled to $0.01^{\circ}$ spatial resolution in the WGS-84 coordinate system [8].

\subsection{Potential forest-cover distribution maps by HyTAG}

Choi et al. [28] found optimal distribution range by tree species using the HyTAG model with a hydrological index (Precipitation Effectiveness Index PEI) and thermal indices (Warmth Index WI; Minimum Temperature of the Coldest Month Index MTCI). Optimal range of the current forest cover distribution was detected after extracting optimal ranges of PEI, WI and MTCI by tree species, using actual vegetation maps and present climatic data [28]. Distributions of future WI, PEI, and MTCI from future climatic data were constructed. Then, potentially optimal forest cover distribution could be determined within the range of future indices. In the present study, HyTAG was used to predict potential forest cover and volume with future climatic data.

\subsection{Methods}

A diagram of the method is shown in Figure 3. This study was performed in four steps, which were to (i) develop forest growth models using NFI data; (ii) combine current (actual) forest cover maps ( $D B H$ class, age class, canopy closure) and develop the forest growth model; (iii) to identify forest cover change considering final cutting age; and (iv) estimate forest volume and carbon storage using the growth model.

\subsubsection{Forest growth models}

The growth models were developed using NFI data and were used to calculate forest volume from the 4th forest cover map. The NFI data include tree species information, mean tree height, $D B H$, age, and number of trees in each plot. To develop the growth models, we first identified rela-
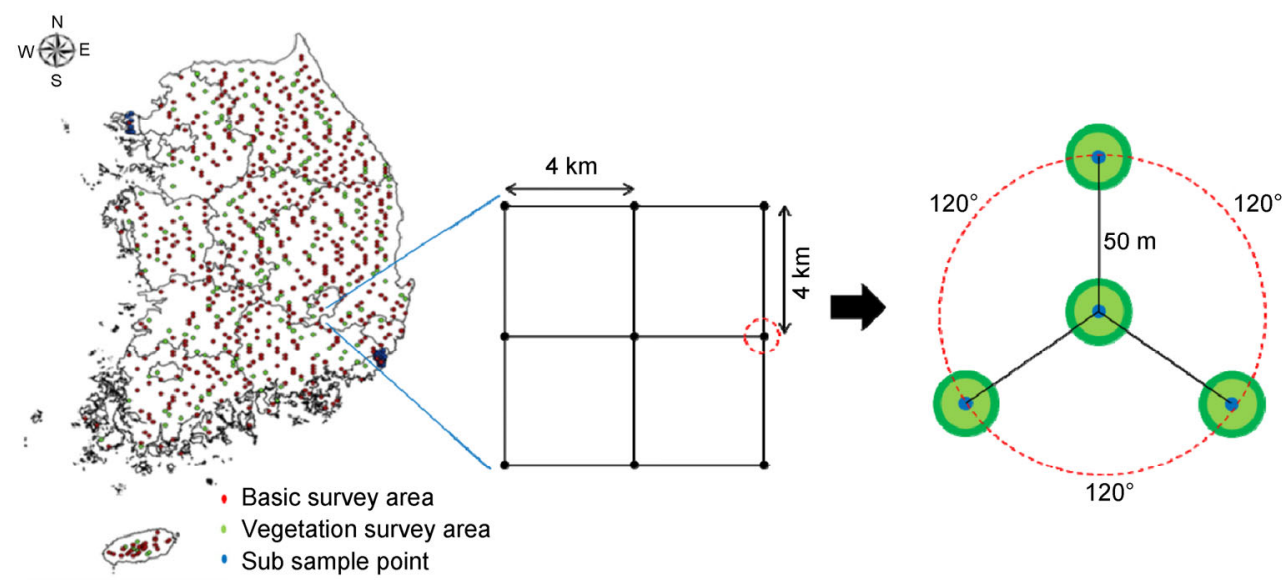

Figure 2 Plot system for the 5th National Forest Inventory (Korea Forest Research Institute 2011) [31]. 


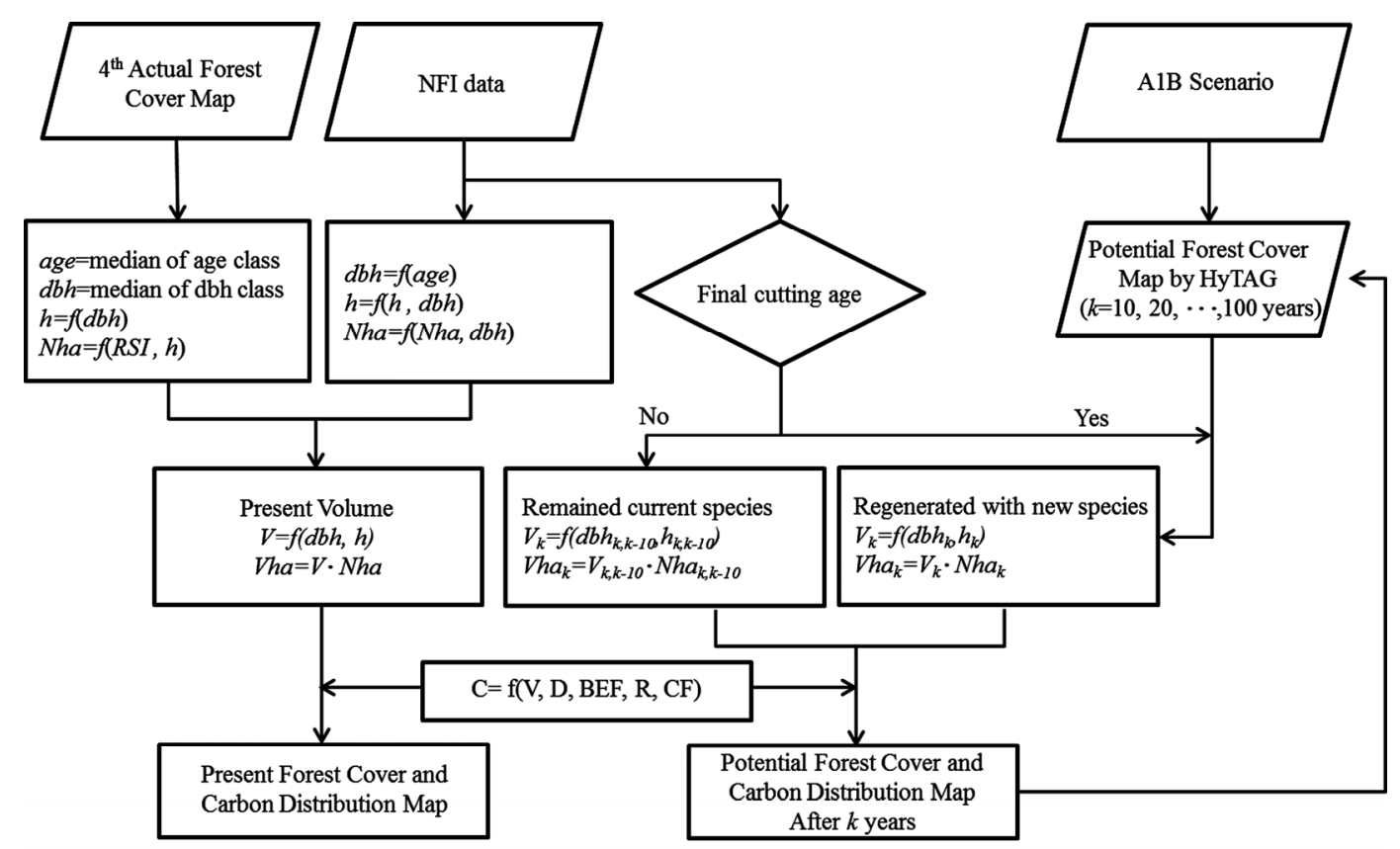

Figure 3 Process for identifying forest cover and carbon storage. V, Volume; BWD, basic wood density; BEF, biomass expansion factor; BSR, root-shoot ratio; $\mathrm{CF}$, carbon fraction.

tionships between (i) $D B H$ and age, (ii) tree height and $D B H$, (iii) $D B H$ and number of trees, and (iv) volume, $\mathrm{DBH}$, and tree height. Considering the relationships and growth characteristics, growth models were developed using the functions in Table 1. Basic forms of the regression equations were described by Sit and Poulin-Costello [39]. Nonlinear regression analyses were conducted for each tree species using SAS 9.2 software [40].

For this study, we used six major tree species, Pinus densiflora, Pinus koraiensis, Pinus rigida, Larix kaempferi, Castanea crenata, and Quercus spp. based on the classification of the forest cover map even though there was information on eight tree species in that map. Other deciduous broadleaf forest trees were assigned to Quercus spp. because they occupied small areas that could not be resolved by the spatial resolution $\left(0.01^{\circ}\right)$.

\subsubsection{Combination of actual forest cover map and forest growth model}

To identify growth factors from the forest cover map for use in the growth models, we extracted $D B H$, age, height, and number of trees per $\mathrm{hm}^{2}$ from the map. This map does not have actual age and $D B H$, but only age class in 10-year intervals and $D B H$ class in 10 -cm intervals. Therefore, we

Table 1 Regression forms to estimate diameter at breast height $(D B H)$, stem number per $\mathrm{hm}^{2}(N h a)$, and height $(h)$

\begin{tabular}{cccc}
\hline No. & Function name & No. of coefficients & Function \\
\hline 1 & Power & 2 & $D B H=a \cdot A g e^{b}$ \\
2 & Power & 2 & $N h a=a \cdot D B H^{b}$ \\
3 & Michailow & 2 & $h=1.2+a \cdot \mathrm{e}^{b / D B H}$ \\
\hline
\end{tabular}

took median values of $D B H$ and age class from the map to derive representative values of $D B H$ and age. Heights and numbers of trees per $\mathrm{hm}^{2}$ are also essential for calculating the forest volume, but the forest cover map does not provide such information. Therefore, the height and number of tree per $\mathrm{hm}^{2}$ were estimated using other growth factors in the forest cover map. Several studies have shown that height and $D B H$ are strongly correlated [41-43]; hence, we used the Michailow function [44] to estimate height from $D B H$. The canopy closure class represents stand density in the forest cover map, but this class does not directly indicate the number of trees per $\mathrm{hm}^{2}$. Therefore, number was estimated by applying the Relative Spacing Index (RSI). This index represents the average distance to the dominant tree height in percent as shown in eq. (1), and can be transformed to number of trees per $\mathrm{hm}^{2}$ via eq. (2) [45-48].

$$
\begin{gathered}
R S I=\frac{\sqrt{\frac{10,000}{N}}}{h_{o}} \times 100, \\
N=\frac{10,000}{R S I^{2} h_{o}^{2}},
\end{gathered}
$$

where $N$ is the stem number per $\mathrm{hm}^{2}$, and $h_{o}$ is dominant tree height.

\subsubsection{Forest cover change}

The final cutting age was used to determine when forest cover changes in a stand. Current actual forest cover was assumed replaced by the potential forest cover predicted by 
the HyTAG model when current stand age of actual forest cover reached final cutting age. If stand age reached final cutting age and the potential forest cover predicted by HyTAG were identical for a tree species, the same forest cover would be regenerated. However, if the potential forest cover from HyTAG was not identical for the tree species, forest cover of the stand at that time would be regenerated by a new potential forest cover using HyTAG. All new regenerated species would have been counted as five years old, because we did not consider forest management during the regeneration. Final cutting age of the national forest [50] was applied when analyzing forest cover change (Table 2).

\subsubsection{Change in forest volume and carbon storage}

To calculate forest volume by tree species, we used the following volume model (eq. (3)). Coefficients proposed by the Korea Forest Service [33] are shown in Table 3.

$$
v=a \cdot D B H^{b} \cdot h^{c} .
$$

Carbon storage can be estimated by multiplying forest volume by carbon emission factors, which are expressed by basic wood density $(B W D)$, biomass expansion factor $(B E F)$, root-shoot ratio $(R S R)$, and carbon fraction $(C F)$ following eq. (4).

$$
C_{i}=v_{i} \cdot B W D \cdot B E F \cdot(1+R S R) \cdot C F .
$$

The carbon emission factors depend on biophysical characteristics of tree species [17]. Table 4 lists these factors for the major species.

In general, future forest growth under different growth conditions such as site index and stand density can be esti- mated by a regression function because those conditions are involved and reflected in the regression function $[16,47,49,50]$. In our study, however, the site index, was not used to explain various growth conditions. Instead, we assumed that current $D B H$ and height represent the site and growth conditions. Toward such a representation, we used algebraic difference forms for estimating future growth, based on current growth. Therefore, it was possible to estimate $D B H, h, N h a, v$ for a subsequent period $(i+10)$, based on current growth status $i$ (Table 5).

\section{Results}

\subsection{Parameters of growth models}

Using the nonlinear regression procedure with NFI data, parameters of each growth model in Table 1 were estimated by tree species (Table 6 ). A pseudo $R^{2}$ was to evaluate performance of the nonlinear regression model [51]. The pseudo $R^{2}$ of the relationships between age, $D B H$, height and number of trees per $\mathrm{hm}^{2}$ ranged from 0.25 to 0.77 . Such relatively low values reflect the fact that diverse topographic, climatic and environmental conditions in South Korea have fostered a variety of forest growth.

All coefficients were found to be highly significant with significance level 0.05. Furthermore, the sign of coefficient $b$ in Michailow's height model growth characteristics well. A negative $b$ signifies that height has a positive relationship with $D B H$. A positive $b$ of $D B H$ indicates that $D B H$ grows with age. A negative $b$ for number of trees per $\mathrm{hm}^{2}$ implies that this number is negative correlated with $\mathrm{DBH}$ [52].

\begin{tabular}{|c|c|c|c|c|c|c|}
\hline Ownership & Pinus densiflora & Pinus koraiensis & Pinus rigida & Larix kaempferi & Castanea crenata & Quercus spp. \\
\hline National forest & 70 & 70 & 35 & 60 & 70 & 70 \\
\hline Public and private forest & 50 & 60 & 25 & 40 & 50 & 50 \\
\hline
\end{tabular}

Table 2 Final cutting age based on ownership

\begin{tabular}{|c|c|c|c|c|c|c|}
\hline Coefficient & Pinus densiflora & Pinus koraiensis & Pinus rigida & Larix kaempferi & Castanea crenata & Quercus spp. \\
\hline$a$ & 0.000201 & 0.000088 & 0.000015 & 0.000047 & 0.000344 & 0.000259 \\
\hline$b$ & 1.7593 & 1.7828 & 2.4239 & 1.8603 & 1.3639 & 1.7043 \\
\hline$c$ & 0.6583 & 0.9397 & 0.8651 & 1.0589 & 0.8790 & 0.6045 \\
\hline
\end{tabular}

Table 3 Coefficients for mean volume equations $\left(v=a \cdot D B H^{b} \cdot h^{c}\right)$ by tree species, developed by Korea Forest Service [34] ${ }^{\mathrm{a}}$

a) $v$, volume, in $\mathrm{m}^{3} ; \mathrm{DBH}$, in $\mathrm{cm} ; h$, height, in $\mathrm{m}$.

Table 4 Carbon emission factors of the major tree species [17]

\begin{tabular}{cccc}
\hline Tree species & Basic wood density (BWD) & Biomass expansion factor (BEF) & Root-shoot ratio (RSR) \\
\hline Pinus densiflora & 0.47 & 1.4 & 0.25 \\
Pinus koraiensis & 0.41 & 1.85 & 0.26 \\
Pinus rigida & 0.51 & 1.39 & 0.43 \\
Larix kaempferi & 0.45 & 1.32 & 0.28 \\
Castanea crenata & 0.66 & 1.5 & 0.42 \\
Quercus spp. & 0.66 & 1.5 & 0.42 \\
\hline
\end{tabular}


Table 5 Algebraic difference forms of the growth models ${ }^{\text {a) }}$

\begin{tabular}{cc}
\hline No. & Function \\
\hline 1 & $N_{i+10}=N_{i}\left(\frac{D B H_{i+10}}{D B H_{i}}\right)^{b}$ \\
2 & $h_{i+10}=h_{i} \cdot \frac{1.2+a \cdot e^{\frac{b}{D B H_{i+10}}}}{1.2+a \cdot e^{\frac{b}{D B H_{i}}}}$ \\
4 & $v_{i+10}=v_{i} \cdot\left(\frac{D B H_{i+10}}{D B H_{i}}\right)^{b} \cdot\left(\frac{h_{i+10}}{h_{i}}\right)^{c}$ \\
\hline
\end{tabular}

a) $X_{i}$, growth in current period, $i ; X_{i+10}$, growth in next period, $i+10$.

\subsection{Pattern of potential forest cover distribution}

Based on the analysis of the future forest cover change, $\sim 39 \%\left(2326853 \mathrm{hm}^{2}\right)$ of the total forest area would rapidly change into deciduous broadleaf forest over the next century. In particular, about $53 \%\left(1455177 \mathrm{hm}^{2}\right)$ of coniferous forest would transition to deciduous broadleaf forest over the next 50 years (2060), as shown in Figure 4. Between 2060 and $2110,13 \%\left(826814 \mathrm{hm}^{2}\right)$ of the coniferous forest would change into deciduous broadleaf forest. Thus, only $8 \%$ $\left(468445 \mathrm{hm}^{2}\right)$ of the coniferous forest area would remain after 100 years. These results suggest that this forest is more vulnerable to climate change than deciduous broadleaf forest $[8,9]$ in South Korea. Noticeable change in forest cover

Table 6 Estimated coefficients of functions in Table 1 for all tree species

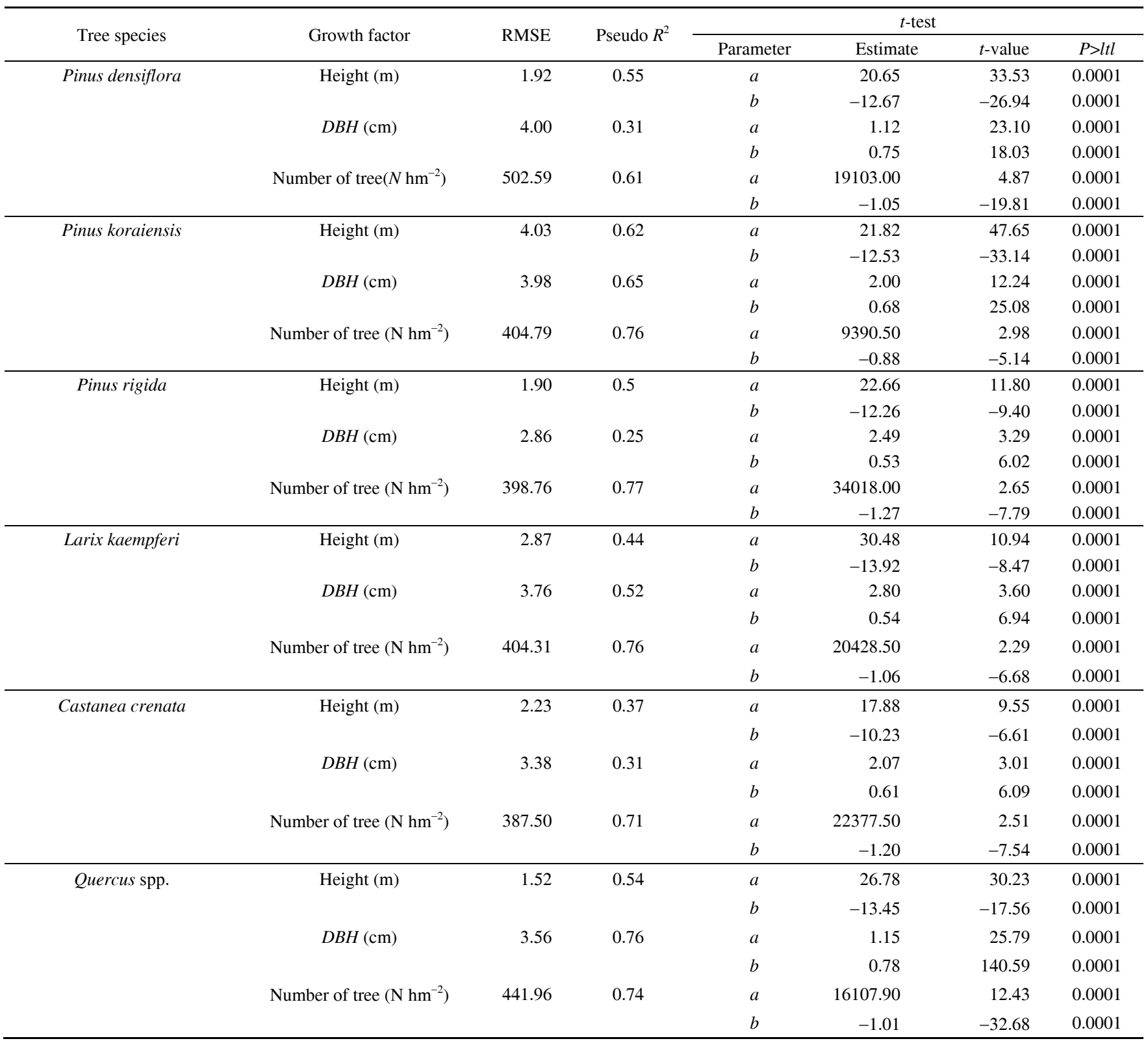



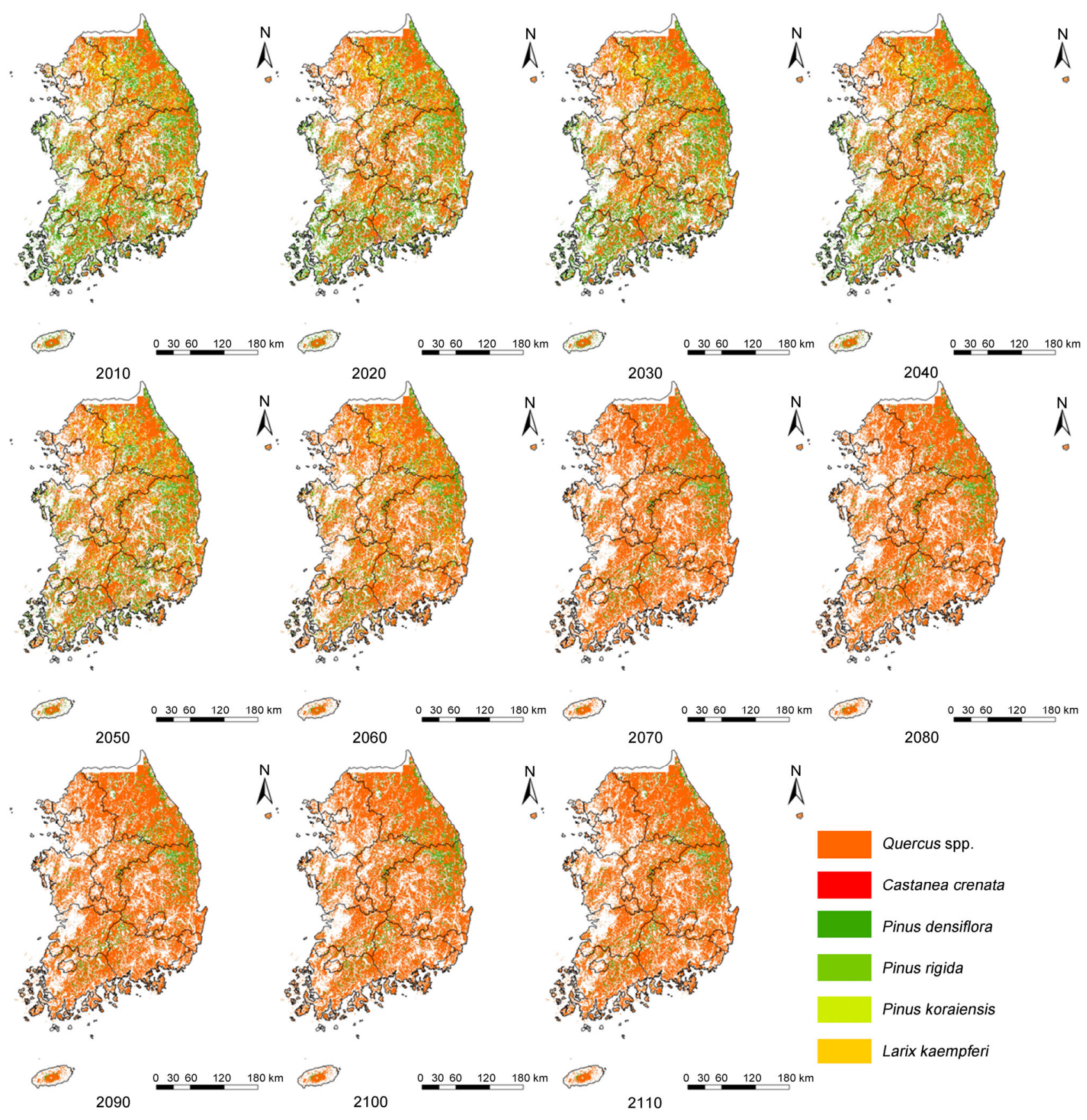

Figure 4 Forest cover change with time over the next 100 years.

was revealed between 2010 and 2060 (Figure 4). This is attributed to the fact that forests with age classes III to IV (21-40 years) occupy $66 \%$ of forest area as of 2010 [53]. Such forests will thus begin to reach final cutting age by 2060.

Such sudden forest cover change over a century might be possible because we did not use regular yield control by considering forest management budgets, practice restriction for forest protection, and conservation. If such yield control was implemented to avoid sudden forest cover change, the coniferous forest might not change as rapidly to deciduous broadleaf forest over the next century.

\subsection{Future forest volume and carbon storage}

Future forest volume was estimated based on algebraic difference forms of growth models (Tables 5 and 7). The present (2010) volume $\left(126.73 \mathrm{~m}^{3} \mathrm{hm}^{-2}\right)$ approximates actual statistics reported in the statistical yearbook of forestry $\left(125.61 \mathrm{~m}^{3} \mathrm{hm}^{-2}\right)$. The annual volume rate increase $(5.21 \%)$ is also nearly identical to that listed in the yearbook $(5 \%)$. From 2010 to 2040, forest volume per ha would increase 
Table 7 Forest volume and carbon storage change in South Korea

\begin{tabular}{|c|c|c|c|c|c|c|c|c|c|c|c|c|}
\hline \multicolumn{2}{|l|}{ Species } & $2010 \mathrm{~s}$ & $2020 s$ & $2030 \mathrm{~s}$ & $2040 s$ & $2050 \mathrm{~s}$ & $2060 s$ & $2070 s$ & $2080 \mathrm{~s}$ & $2090 s$ & $2100 \mathrm{~s}$ & $2110 \mathrm{~s}$ \\
\hline \multirow[t]{2}{*}{ Pinus densiflora } & $\mathrm{m}^{3} \mathrm{hm}^{-2}$ & 146.83 & 197.14 & 242.56 & 274.3 & 297.83 & 258.29 & 86.53 & 122.86 & 153.11 & 179.48 & 200.57 \\
\hline & $\mathrm{tC} \mathrm{hm}^{-2}$ & 60.38 & 81.08 & 99.75 & 112.81 & 122.48 & 106.22 & 35.59 & 50.53 & 62.96 & 73.81 & 82.49 \\
\hline \multirow[t]{2}{*}{ Pinus koraiensis } & $\mathrm{m}^{3} \mathrm{hm}^{-2}$ & 140.39 & 265.42 & 394.1 & 526.28 & 671.6 & 908.24 & 72.44 & 120.16 & 164.46 & 203.77 & 232.57 \\
\hline & $\mathrm{tC} \mathrm{hm} \mathrm{m}^{-2}$ & 67.09 & 126.83 & 188.32 & 251.49 & 320.93 & 434.01 & 34.61 & 57.42 & 78.59 & 97.37 & 111.14 \\
\hline \multirow[t]{2}{*}{ Pinus rigida } & $\mathrm{m}^{3} \mathrm{hm}^{-2}$ & 114.55 & 147.16 & 171.44 & 190.79 & 209.82 & 343.75 & - & - & - & - & - \\
\hline & $\mathrm{tC} \mathrm{hm}^{-2}$ & 80.52 & 103.44 & 120.51 & 134.11 & 147.48 & 241.62 & - & - & - & - & - \\
\hline Larix kaempferi & $\mathrm{tC} \mathrm{hm}{ }^{-2}$ & 29.8 & 48.99 & 68.04 & 87.28 & 117.94 & 33.4 & 53.64 & 71.03 & 85.02 & 95.19 & 98.99 \\
\hline \multirow[t]{2}{*}{ Castanea crenata } & $\mathrm{m}^{3} \mathrm{hm}^{-2}$ & 70.59 & 33.36 & 50.32 & 82.37 & 79.66 & - & - & - & - & - & - \\
\hline & $\mathrm{tC} \mathrm{hm}^{-2}$ & 35.78 & 16.91 & 25.51 & 41.75 & 40.38 & - & - & - & - & - & - \\
\hline \multirow[t]{2}{*}{ Quercus spp. } & $\mathrm{m}^{3} \mathrm{hm}^{-2}$ & 128.66 & 164.36 & 200.54 & 219.84 & 174.43 & 117.02 & 97.95 & 140.04 & 169.44 & 197.71 & 207.3 \\
\hline & $\mathrm{tC} \mathrm{hm}^{-2}$ & 90.44 & 115.53 & 140.96 & 154.52 & 122.6 & 82.25 & 68.85 & 98.44 & 119.1 & 138.97 & 145.71 \\
\hline \multirow[t]{2}{*}{ Mean } & $\mathrm{m}^{3} \mathrm{hm}^{-2}$ & 126.73 & 171.34 & 214.93 & 243.55 & 223.85 & 153.69 & 97.38 & 138.99 & 168.54 & 196.51 & 206.96 \\
\hline & $\mathrm{tC} \mathrm{hm} \mathrm{m}^{-2}$ & 72.89 & 98.44 & 123.14 & 139.28 & 128.77 & 93.7 & 65.54 & 93.61 & 113.48 & 132.57 & 140.62 \\
\hline No species change & $\mathrm{tC} \mathrm{hm}^{-2}$ & 72.89 & 101.2 & 127.29 & 151.38 & 173.83 & 194.91 & 214.84 & 233.79 & 251.88 & 269.23 & 285.93 \\
\hline
\end{tabular}

from 126.73 to $188.64 \mathrm{~m}^{3} \mathrm{hm}^{-2}\left(61.91 \mathrm{~m}^{3} \mathrm{hm}^{-2}\right.$ or $\left.49 \%\right)$. From 2070 to 2110 , this would increase from 75.22 to $157.33 \mathrm{~m}^{3} \mathrm{hm}^{-2}\left(82.11 \mathrm{~m}^{3} \mathrm{hm}^{-2}\right.$ or $\left.109 \%\right)$. However, from 2040 to 2070 , there would be a decrease from 188.64 to $75.22 \mathrm{~m}^{3} \mathrm{hm}^{-2}\left(113.42 \mathrm{~m}^{3} \mathrm{hm}^{-2}\right.$ or $\left.60 \%\right)$ because most forest ages will reach final cutting age between 2040 and 2060 and will hence be cut and replaced by new tree species.

From 2010 to 2040, forest carbon storage per ha would increase from 72.89 to $106.89 \mathrm{Mg} \mathrm{C} \mathrm{hm}^{-2}\left(34 \mathrm{Mg} \mathrm{C} \mathrm{hm}^{-2}\right.$ or $47 \%$ ). From 2070 to 2110 , the increase would be from 50.47 to $106.74 \mathrm{Mg} \mathrm{C} \mathrm{hm}^{-2}\left(115 \%\right.$ by $56.27 \mathrm{Mg} \mathrm{C} \mathrm{hm}^{-2}$ ). However, from 2040 to 2070 , there would be a steep decrease from 106.89 to $50.47 \mathrm{Mg} \mathrm{C} \mathrm{hm}^{-2}$ (56.42 $\mathrm{Mg} \mathrm{C} \mathrm{hm}^{-2}$ or $53 \%$ ) (Table 7).

\section{Discussion}

It was predicted that the forest volume would increase to $223.85 \mathrm{~m}^{3} \mathrm{hm}^{-2}$ by 2050 . However, volume was overestimated compared with the 5th Forest Master Plan of South Korea, in which total forest volume in 2050 was estimated at $138 \mathrm{~m}^{3} \mathrm{hm}^{-2}$ [53]. Moreover, Yu et al. [54] estimated that forest volume would be $226.81 \mathrm{~m}^{3} \mathrm{hm}^{-2}$ within 50 years. In contrast, Kwak et al. [16] predicted that this volume would decrease rapidly to $43.59 \mathrm{~m}^{3} \mathrm{hm}^{-2}$ in the next 50 years. Such variable results are attributed to differences of approach to regeneration and yield control. The prediction by Kwak et al. was the lowest because forest cover change was evaluated only using an equilibrium model without consideration of gradual migration and immigration (natural regeneration). In contrast, Yu et al. estimated forest volume only through the relationship between age and volume, without accounting for change in forest cover; thus the volume would increase continuously according to the general growth law.

Volume in the control case continuously increased to
$507.26 \mathrm{~m}^{3} \mathrm{hm}^{-2}$ over the next 100 years, which is an estimate under the assumption that the tree species will not change (Figure 5). In this case, the mean volume increment during 2010-2110 would decline from $3.77 \%$ to $0.68 \%$ as forest age increases (Table 8 ). However, mean volume under a scenario of artificial regeneration with a final cutting age would rise because of vigorous growth of the regenerated forest, even if total volume decreases as shown in Table 7 .

Therefore, our approach is more accurate than earlier studies [16,54], because of realistic approximation using the estimate of the 5th Forest Master Plan of South Korea and a growth rate superior to that of the case without tree species change.

We compared $R^{2}$ and RMSE to those of the statistical yearbook of forestry in South Korea between 2000 and 2010. We thereby obtained, $R^{2}$ and RMSE of 0.61 and 17.21 $\mathrm{m}^{3} \mathrm{hm}^{-2}$, respectively. Therefore, our result is appropriate for estimation of future volume (Figure 6).

Table 8 Comparison of growth rate between final cutting age and no species change

\begin{tabular}{ccc}
\hline \multirow{2}{*}{ Years } & \multicolumn{2}{c}{ Growth rate $(\%)$} \\
\cline { 2 - 3 } & Final cutting age & No species change \\
\hline $2010 \mathrm{~s}$ & 5.9 & 5.9 \\
$2010-2020 \mathrm{~s}$ & 3.83 & 3.77 \\
$2020-2030 \mathrm{~s}$ & 2.64 & 2.62 \\
$2030-2040 \mathrm{~s}$ & 2.04 & 1.98 \\
$2040-2050 \mathrm{~s}$ & 2.66 & 1.57 \\
$2050-2060 \mathrm{~s}$ & 3.14 & 1.30 \\
$2060-2070 \mathrm{~s}$ & 5.48 & 1.10 \\
$2070-2080 \mathrm{~s}$ & 6.90 & 0.96 \\
$2080-2090 \mathrm{~s}$ & 2.79 & 0.84 \\
$2090-2100 \mathrm{~s}$ & 2.17 & 0.75 \\
$2100-2110 \mathrm{~s}$ & 1.77 & 0.68 \\
\hline
\end{tabular}




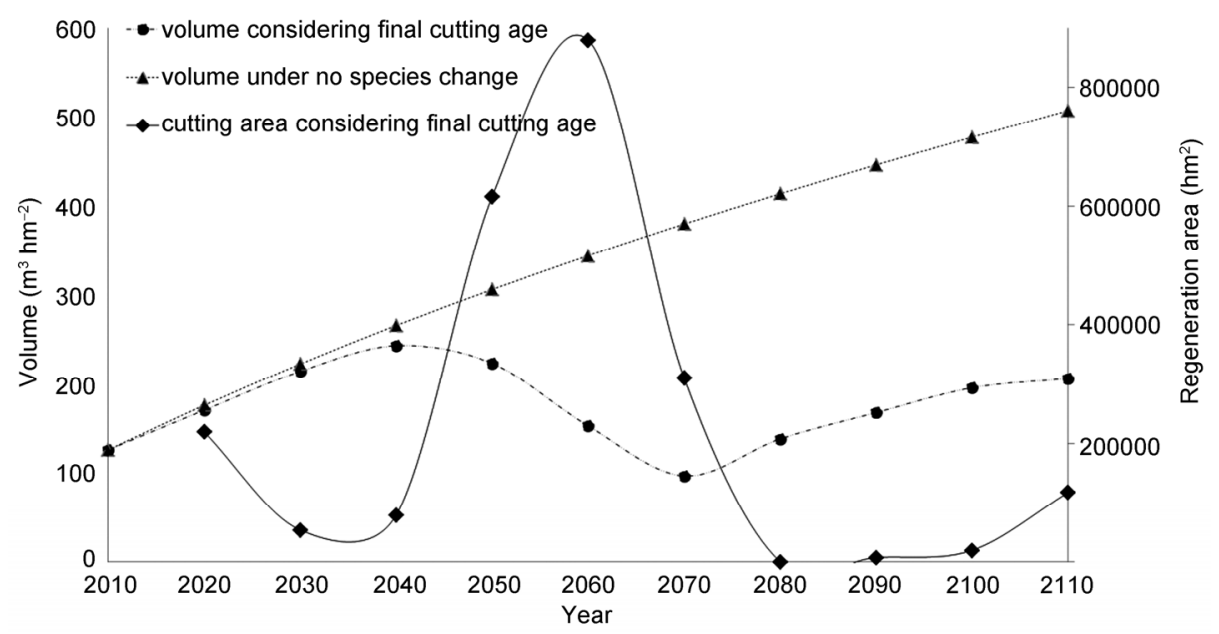

Figure 5 Change in volume and regeneration area.

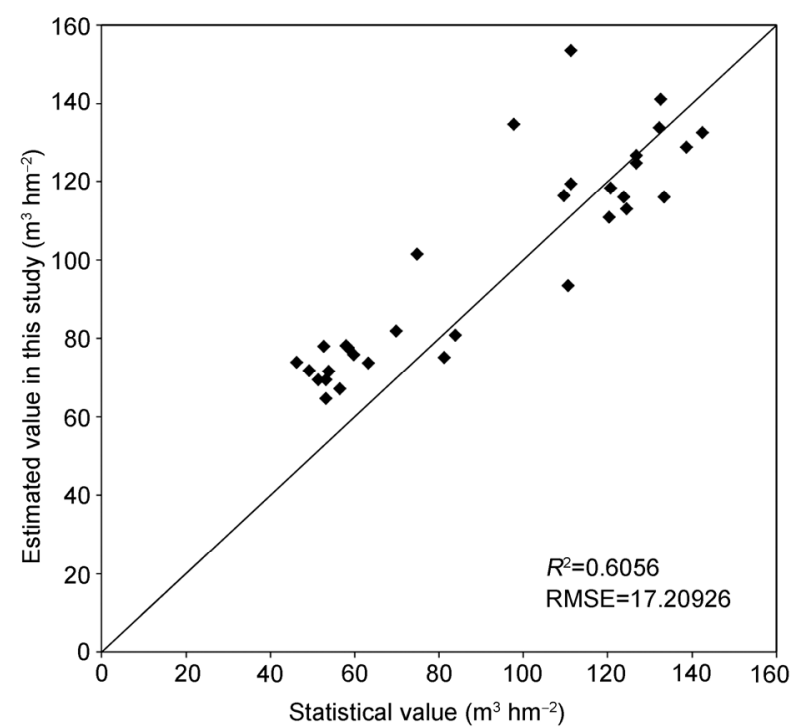

Figure 6 Comparison of estimated values in this study and statistical values.

Bare mountains in South Korea have been restored through planting of seedlings on a national basis since 1960s. This afforestation has led to the current forest in age classes III and IV (66\%), which will reach final cutting age between 2060 and 2070 [53]. Therefore, excessive cutting and regeneration can cause forest volume and carbon storage to abruptly decrease by 2070 (Figure 5). However, our research does not indicate a huge amount of deforestation in this period, but rather suggests a solution to avoid this drastic forest cutting. To avoid such rapid change in the forest cover, volume, and carbon storage, a regeneration or yield control scheme should be planned and implemented in a way that ensures balance of forest practice and yield (volume and carbon storage) [55]. For maintaining balance and establishing normal regeneration in each year at a national level, a priority order of regeneration should be determined with consideration of forest status, practice and budget. Thereby, optimal regeneration or yield schemes can be constructed with consideration of sustainable forest practice [55] and potential forest cover under climate change [28].

Studies using the MC1, CEVSA, and HyTAG models showed that in the future Korea, coniferous forests would decrease and broadleaf forest increase (mostly Quercus spp.). Using HyTAG, Kwak et al. [16] predicted that $99 \%$ of total forest would be composed of Quercus spp. after the passage of 100 years. Lee [8] also showed that coniferous forest would decrease, from $40 \%$ to $5 \%$. Using MC1, Choi et al. [26] predicted $40 \%$ change for different forest tree species. Byun et al. [56], stated that because of climate change, the growth of Pinus densiflora will decrease and that of Quercus spp. will increase. Our study also shows that most of Korean forest will gradually change into Quercus spp. stands in the coming century. With application of the HyTAG model, the results of our study were similar with previous studies. Both our and previous studies excluded efforts toward protecting and maintaining current species. However, we focused on change in forest cover from climate impact. If forest managers strive to maintain current species, the future forest cover would vary from our result. Therefore, we conclude that the dramatic change in forest cover and volume predicted herein should be addressed by implementing plans for controlling forest type and yield.

\section{Conclusion}

This study analyzed changes in forest cover, volume and carbon storage by considering actual and potential forest cover, a forest growth model, and final cutting age of the six major tree species in South Korea. First, we identified forest cover change using the final cutting age. Second, we estimated forest volume by combining the forest cover map and 
forest growth model, which was developed using NFI data.

Approximately $39 \%\left(2326853 \mathrm{hm}^{2}\right)$ of total forest area in Korea is predicted to change rapidly into deciduous broadleaf forest (mainly Quercus spp.) over the next 100 years. Forest volume and carbon storage would continuously increase through 2040, decrease from 2050 to 2070, and then increase again from 2070 to 2110 . Our results imply that forest volume and carbon storage can be altered by forest cover variation induced by climate change.

This study showed that forest cover, volume and carbon storage could abruptly change by 2060 , because many forests were presumed to reach final cutting age and be regenerated with the potential forest cover type. Further studies are needed to prepare optimal regeneration plans to ensure sustainable forest practice that can balance forest volume and carbon budgets.

This work was supported by "Developing Forest Management Model for Climate Change Adaptation" (FE 0100-2009-01) provided by the Korea Forest Research Institute and supported by "Climate Change Correspondence Program" (2014001310008) provided by Ministry of Environment, Korea.

1 IPCC. Climate Change 2007: The physical scientific basis. The Fourth Assessment Report of Working Group. Cambridge: Cambridge University Press, 2007

2 Bonan GB. Forests and climate change: forcings, feedbacks, and the climate benefits of forests. Science, 2008, 320: 1444-1449

3 Han WJ, Ahn S, Yoo G, Hwng JH, Kim JE, Lee JT, Na YE, Kim MH, Son Y, Lee WK, Cho Y, Han KJ, Kim JI, Choi EJ, Kim KN, Bae D, Jung IW. Climate change impact assessment and development of adaptation strategies in Korea II. Korea Environment Institute, 2006

4 Fuchs H, Magdon P, Kleinn C, Flessa H. Estimating aboveground carbon in a catchment of the Siberian forest tundra: combining satellite imagery and field inventory. Remote Sens Environ, 2009, 113: 518-531

5 Neilson RP, Marks D. A global perspective of regional vegetation and hydrological sensitivities from climate change. J Veg Sci, 1994, 5: $175-730$

6 Box EO. Plant functional types and climate at the global scale. J Veg Sci, 1996, 7: 309-320

7 Kong WS. Selection of vulnerable indicator plants by global warming. Asia-Pa J Atm Sci, 2005, 41: 263-273

8 Lee MA, Lee WK, Song CC, Lee JH, Choi HA, Kim TM. Spatio-temporal change prediction and variability of temperature and precipitation. J GIS Assoc KR, 2007, 15: 1-12

9 Choi S, Lee WK, Son Y, Yoo S. Lim JH. Changes in the distribution of South Korean forest vegetation simulated using thermal gradient indices. Sci China Life Sci, 2010, 53: 784-797

10 Korea Forest Service. Statistical Yearbook of Forestry 2011. Korea Forest Service, Seoul, 2011

11 Arris LL, Eagleson PS. Evidence of a physiological basis for the boreal-deciduous forest ecotone in North America. Vegetation, 1989, 82: $55-58$

12 Neilson RP. Transient ecotone response to climate change: Some conceptual and modeling approaches. Ecol Appl, 1993, 3: 385-395

13 Lenihan JM, Drapek R, Bachelet D, Neilson RP. Climate change effects on vegetation distribution, carbon, and fire in California. Ecol Appl, 1993, 13: 1667-1681

14 Laurent JM, Bar-Hen A, Francois L, Ghislain M, Cheddadi R. Refining vegetation simulation models: from plant functional types to bioclimatic affinity groups of plants. J Veg Sci, 2004, 15: 739-746

15 Matsui T, Yagihashi T, Nakaya T, Tanak N, Taoda H. Climate controls on distribution of Fagus crenata forests in Japan. J Veg Sci, 2004, 15: 57-66

16 Kwak DA, Lee WK, Son Y, Choi S, Yoo S, Chung DJ, Lee SH, Kim SH, Choi JK, Lee YJ, Byun WH. Predicting distributional change of forest cover and volume in future climate of South Korea. Forest Sci Technol, 2012, 8: 105-115

17 Son YM, Lee KH, Kim RH, Pyo JK, Park IH, Son Y, LEE YJ, Kim CS. Carbon emission factor of major species for forest greenhouse gas inventory. Korea Forest Research Institute, 2010

18 Prentice IC, Cramer W, Harrison SP, Leemans R, Monserud RA, Solomin AM. A global biome model based on plant physiology and dominance, soil properties and climate. J Biogeogr, 1992, 19: $117-134$

19 Lenihan JM, Neilson RP. A rule-based vegetation formation model for Canada. J Biogeogr, 1993, 20: 615-628

20 Brzeziecki B, Kienast F, Wildi O. Modelling potential impacts of climate change on the spatial distribution of zonal forest communities in Switzerland. J Veg Sci, 1995, 6: 257-268

21 Cao M, Woodward FI. Dynamic responses of terrestrial ecosystem carbon cycling to global climate change. Nature, 1998, 393: 249-252

22 Osborne CP, Mitchell PL, Sheehy JE, Woodward FI. Modeling the recent historical impacts of atmospheric $\mathrm{CO}_{2}$ and climate change on Mediterranean vegetation. Global Change Biol, 2000, 6: 445-458

23 Bachelet D, Lenihan JM, Daly C, Neilson RP, Ojima DS, Parton WJ. $\mathrm{MC1}$ : a dynamic vegetation model for estimating the distribution of vegetation and associated carbon, nutrients, and water technical documentation. Version 1.0. Gen. Tech. Rep. PNW-GTR-508. U.S. Department of Agriculture, Forest Service, Pacific Northwest Research Station, Portland, OR, USA, 2001

24 Watanabe T, Yokozawa M, Emori S, Takata K, Sumida A, Hara T. Developing a multilayered integrated numerical model of surface physics - growing plants interaction (MINoSGI). Global Change Biol, 2004, 10: 963-982.

25 Kim J, Lee D. A study on the vulnerability assessment of forest vegetation using regional climate model. J Korean Env Res Reveg Tech, 2006, 9: 32-40

26 Choi S, Lee WK, Kwak H, Kim SR, Yoo S, Choi HA, Park S, Lim $\mathrm{JH}$. Vulnerability assessment of forest ecosystem to climate change in Korea using MC1 model. Jpn J For Plan, 2011, 16: 149-161

27 Kim SA, Lee WK, Son Y, Cho YS, Lee MS. Applicability of climate change impact assessment models to Korean forest. J Korean For Soc, 2009, 98: 1-16

28 Choi S, Lee WK, Kwak DA, Lee S, Son Y, Lim JH, Saborowski J. Predicting forest cover changes in future climate using hydrological and thermal indices in South Korea. Climate Res, 2011, 49: 229-245

29 Korea Forest Research Institute. Standardized Production System for Digital Forest Type Map (1:25000). Korea Forest Research Institute, Seoul, South Korea, 2008

30 Lee WK. Estimation of carbon stock in future climate using NFI and remotely sensed data in South Korea. International Symposium on a New Era of Forest Management for Ecosystem Services, 2012. 17-20

31 Korea Forest Research Institute. The 5th National Forestry Inventory Report. Korea Forest Research Institute, Seoul, South Korea, 2011

32 Lee CS, Lee WK, Yoon JH, Song CC. Distribution pattern of Pinus densiflora and Quercus spp. stand Korea using spatial statistics and GIS. J Korean For Soc, 2006, 95: 663-671

33 Korea Forest Service. Forest and forestry technique. Korea Forest Service, Daejeon, South Korea, 2000

34 Lull H W, Ellison L. Precipitation in Relation to Altitude in Central Utah. Ecology, 1950, 31:479-484

35 Yun J I, Choi J Y, Ahn J H. Seasonal Trend of Elevation Effect on Daily Air Temperature in Korea. Korean J Agr For Meteorol, 2001, 3: 96-104

36 Cho H, Jeong J. Application of Spatial Interpolation to Rainfall Data. J GIS Assoc KR, 2006, 14: 29-41

37 Park N W, Jang D H. Mapping of Temperature and Rainfall Using DEM and Multivariate Kriging. J Korean Geogr Soc, 2008, 43: 1002-1015

38 IPCC. Special report on emissions scenarios. Cambridge University 
Press, Cambridge, United Kingdom, 2000

39 Sit V, Poulin-Costello M. Catalog of Curves for Curve Fitting. Forest Science Research Branch, Ministry of Forests, Victoria, BC, Canada, 1994

40 SAS Institute Inc. SAS user guide. SAS Institute Inc., Cary, NC, USA, 2010

41 Lee WK. Stand and general height-DBH curve models for Pinus densiflora in KangWon Province. Korean J For Economics, 1996, 4: 66-78

42 Gadow Kv, Hui GY. Zur Entwicklung von Einheitshöhenkurven am Beispiel der Baumart Cunninghamia lanceolata. Allgemeine Forst und Jagd Zeitung, 1993, 110: 41-48

43 Wenk G, Antanaitis V, Šmelko Š. Waldertragslehre. Deutscher Landwirtschaftsverlag, Berlin, Germany, 1990

44 Michailow I. Zahlenmäßiges Verfahren für die Ausführung der Bestandeshöhenkurven. Fw Cbl U That Forstl Jahrb Heft, 1943, 6: 273-279

45 Gadow Kv. Wachstums- und Ertragsmodelle für die Forsteinrichtung. Deutscher Verband Forstl Forsch Anst, Sektion Ertragskunde. Jahrestagung in Grillenberg, 1992

46 Lee WK. A Dynamic regional forest management model for the sustainability of forest practice-considering forest growth and economical conditions. Korean J For Economics, 1995 3: 71-98

47 Woo J, Ahn J, Yoon H, Lee D, Lee S. Forest management. Hyanmunsa, 2007, 78-242
48 Zhao DH, Kane M, Borders BE. Development and applications of the relative spacing model for loblolly pine plantations. For Ecol Manage, 2010, 259: 1922-1929

49 Byun WH, Lee WK, Bae SW. Forest growth. Yoochun Media, 1996, 93-123

50 Lee WK, Seo JH, Bae SW. Maximum stem number and mortality model for even-aged Pinus densiflora stand in Kangwon-Province, Korea. J Korean For Soc, 2000, 89: 634-644

51 Schabenberger O, Pierce FJ. Contemporary statistical models for the plant and soil sciences. New York: CRC Press, 2002

52 Reineke LH. Perfecting a stand density index for even-aged forests. J Agric Res, 1993, 46: 627-638

53 Korea Forest Service. The 5th Forest Master Plan. Korea Forest Service, Daejeon, South Korea, 2005

54 Yu H, Lee WK, Son Y, Kwak DA, Nam KJ, Kim MI, Byun JY, Lee SJ, Kwon T. Estimating carbon stock in Korean forests between 2010 and 2110: A prediction based on forest volume-age relationships. For Sci Technol, 2013, 9: 105-110

55 Lee WK, Biging GS, von Gadow Kv, Byun WH. A forest planning model for continuous employment in a forested village with primarily young stands in Korea. New Forests, 2005, 29: 15-32

56 Byun JG, Lee WK, Kim MI, Kwak DA, Kwak H, Park T, Byun WH, Son Y, Choi JK, Lee YJ, Saborowski J, Chung DJ, Jung JH. Radial growth response of Pinus densiflora and Quercus spp. to topographic and climatic factors in South Korea. J Plant Ecol, 2013, 6: 380-392

Open Access This article is distributed under the terms of the Creative Commons Attribution License which permits any use, distribution, and reproduction in any medium, provided the original author(s) and source are credited. 